\title{
Structural Architecture of the Kura Foreland Fold-and-thrust Belt Using Seismic Reflection Profile, Georgia
}

\author{
Victor Alania ${ }^{1, *}$, Onise Enukidze ${ }^{1}$, Nugzar Glonti ${ }^{1}$, Alexander Razmadze ${ }^{1}$, \\ Alexander Chabukiani ${ }^{1}$, Anzor Giorgadze ${ }^{2}$, Bacho Vakhtang Glonti ${ }^{2}$, \\ Kakhaber Koiava' ${ }^{2}$, Tamar Beridze ${ }^{2}$, Sophio Khutsishvili ${ }^{2}$, Rusudan Chagelishvili ${ }^{3}$ \\ ${ }^{1}$ Institute of Geophysics, Iv. Javakhishvili Tbilisi State University, United States \\ ${ }^{2}$ Al. Janelidze Institute of Geology, Iv. Javakhishvili Tbilisi State University, United States \\ ${ }^{3}$ Department of Geology and Paleontology, Georgian National Museum, United States
}

Copyright $@ 2018$ by authors, all rights reserved. Authors agree that this article remains permanently open access under the terms of the Creative Commons Attribution License 4.0 International License

\begin{abstract}
Our study is focused on the structural geometry of the western part of Kura foreland fold-and-thrust belt (KFFTB) disposed in the central part of the Caucasus. Structural architecture of the Georgian part of the KFFTB has been interpreted using seismic reflection profile. Building of structures of the Kura foreland basin was formed by Greater Caucasus basement wedge propagation along detachment horizons within the cover-generating thin-skinned structures represented by Neogene shallow marine and thick continental sediments. Based on the structural style of deformation, two seismicstructural complexes were identified in seismic profiles: an upper and a lower complex. Seismic reflection data reveal the presence of south-vergent thrusts, north-vergent backthrusts, and duplex. The deformations in the KFFTB structures were controlled by the multi-level detachments. The Didi Shiraki thrust-top basin has a bivergent geometry and is filled by Pliocene-Pleistocene syn-kinematic sediments.
\end{abstract}

Keywords Seismic Profile, Thrust-top Basin, Fault-related Fold, Growth Strata, Duplex

\section{Introduction}

The Kura foreland fold-and-thrust belt (KFFTB), which developed earlier (Oligocene-Lower Miocene) as a foreland basin, is located between the Greater Caucasus and Lesser Caucasus (Figure 1) and is a good example of continental mountain building in the Late Cenozoic [1].

The structure of KFFTB belt has been the subject of study in recent years, and several authors have identified the differences in the structural styles developed [1, 4, 5, 6, $7,8]$. According to the different models of structural style, the kinematics and deformation regimes of the KFFTB are divided into: (1) thin-skinned [1, 5, 7]; and (2) thick-skinned [8, 9, 10, 11] fold-and-thrust belts (FTB).

In this paper, we interpret new seismic reflection profile to reveal the detailed structure of the KFFTB (Figure 4). The seismic interpretation presented here is further constrained by surface geology and subsurface geology revealed by seven well penetrations. These data and constraints are integrated to present a new structural model for the Georgian part of KFFTB. It is known that thrust-top basins are very common features in foreland FTB, and are key elements for unravelling the tectonic evolution of FTB [e.g. 12, 13, 14]. One of such basins is the located in northern part of seismic reflection profile A-B Didi Shiraki basin (Figure 4).

\section{Geological Setting}

Our study is focused on the Georgian part of the KFFTB (Figures 1, 2), where the outcrop strata are mainly Miocene-Quaternary shallow marine and continental deposits (Figure 2). Based on modern and historical earthquake and global positioning system (GPS) data [15], the Kura foreland is an active FTB. According to GPS data, the convergence rate of the Greater Caucasus and Lesser Caucasus mountains increases from west to east in the Caucasus region; the convergence rate in the Rioni Basin is about $4 \mathrm{~mm} \mathrm{a}^{-1}$ and the rate in the Kura foreland (in Azerbaijan) is about $14 \mathrm{~mm} \mathrm{a}^{-1}$ [15]. 


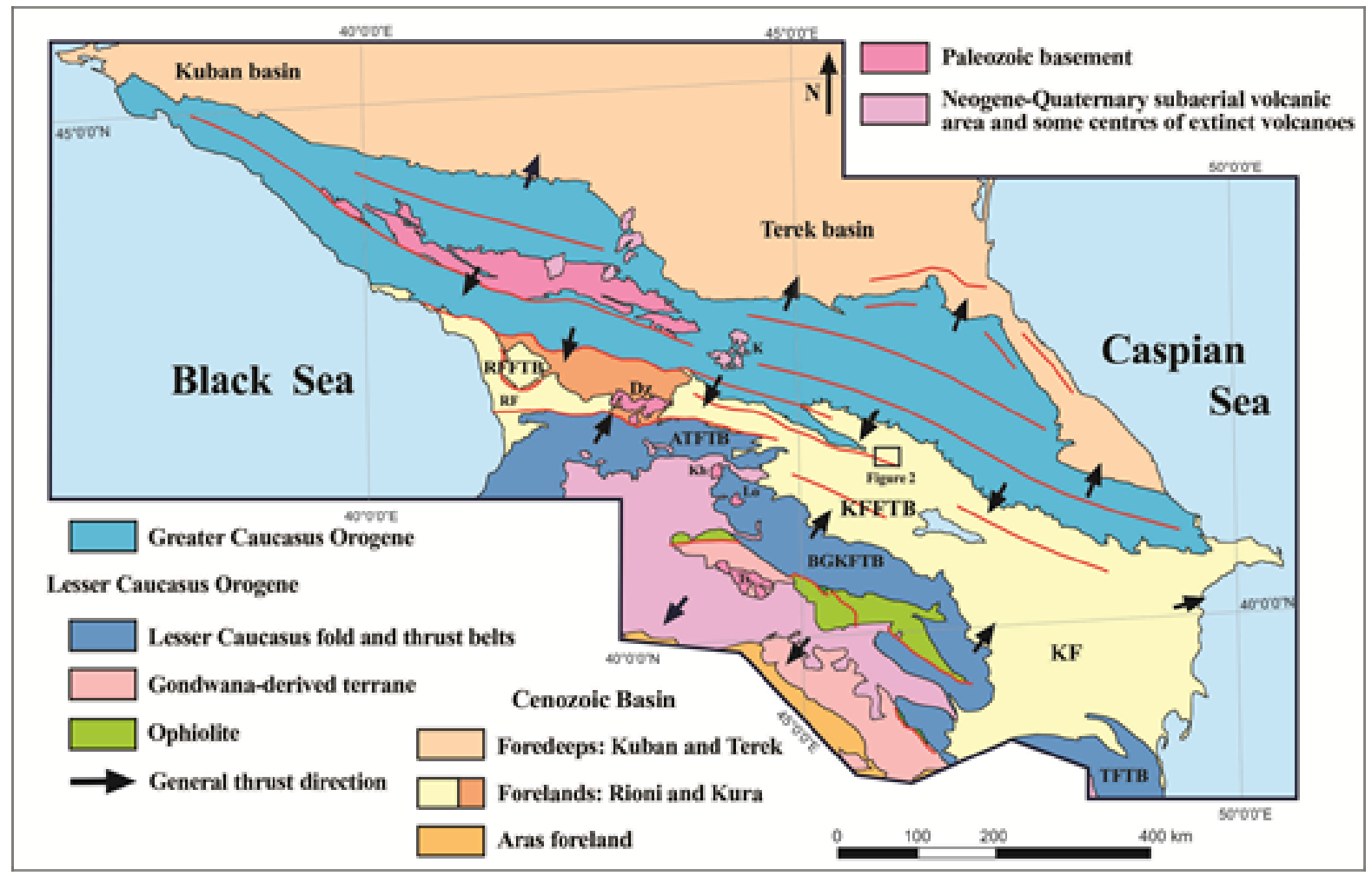

Figure 1. Schematic tectonic map of Caucasus (modified from [1, 2, 3])

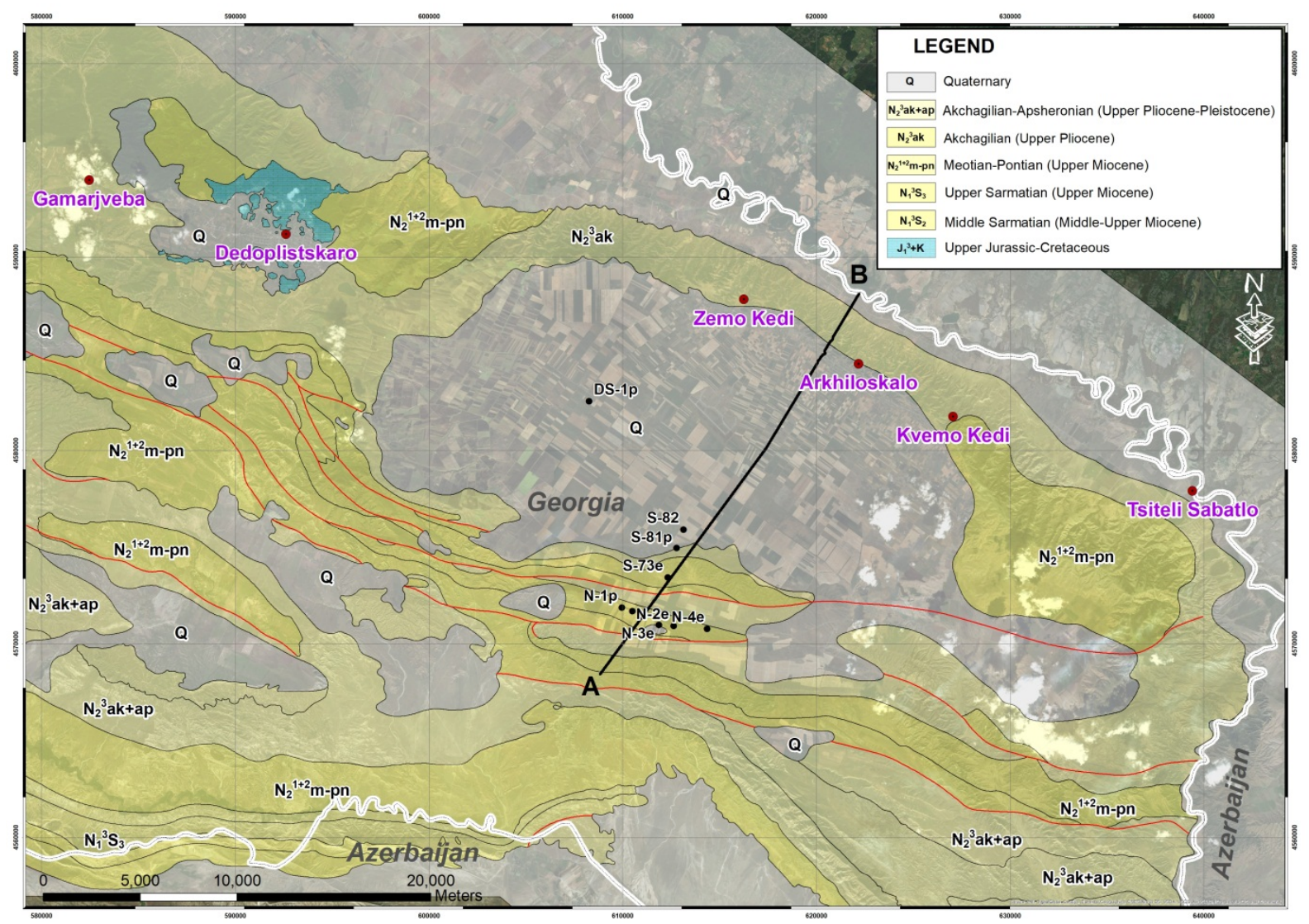

Figure 2. Geological map of the study area 
The orography of the KFFTB is characterized by foothills and depressions. The depressions are filled mainly by Akchagilian-Apsheronian syn-kinematic sediments unconformably overlying the older rocks $[1,4,6]$. Stratigraphy in the KFFTB records the evolution from the foreland basin to the compressive deformation of the Arabia-Eurasia collision zone. Compressional deformation of the Kura foreland started in the Middle Miocene, initially covering the north-most parts of the area, compression reached its peak at the end of the Miocene [1].

The main stratigraphic units of the study area and related tectonic events are schematized in the stratigraphic column of Figure 3. The study area mainly is constituted by Kura foreland basin megasequence (Oligocene-Lower Miocene) and syn-kinematic sediments (Middle Miocene-Pleistocene). Rocks of Oligocene-Early Miocene age in some places conformably follow sandy-clayey sediments of the Late Eocene and are represented all over the Kura foreland by a uniform, mostly clayey, sequence termed here the 'Maikopian series'; locally thin beds and lenses of hematite are also observed as well [5]. The Kura foreland syn-kinematic deposits are represented by shallow marine, continental (Middle-Upper Miocene) and thick continental (Pliocene-Pleistocene) sediments. The thickness of the molasse formations of the Oligocene-Quaternary in the Kura foreland is 7-8 km [16]. The Late Pliocene (Akchagilian) is represented by continental and shallow marine molasse rocks unconformably overlying the older rocks (maximum thickness c. $1500 \mathrm{~m}$ ). The marine facies of the lower part of the section is made up of sandy-clayey rocks and the upper part consists of sandstones and conglomerates. The continental facies of the Akchagilian is represented by conglomerates, sandstones and sandy clays. Thin layers of volcanic ash are found locally [17]. The Pliocene (Apsheronian) continental facies are represented mostly by conglomerates with insignificant sandstones and sandy clays [17].

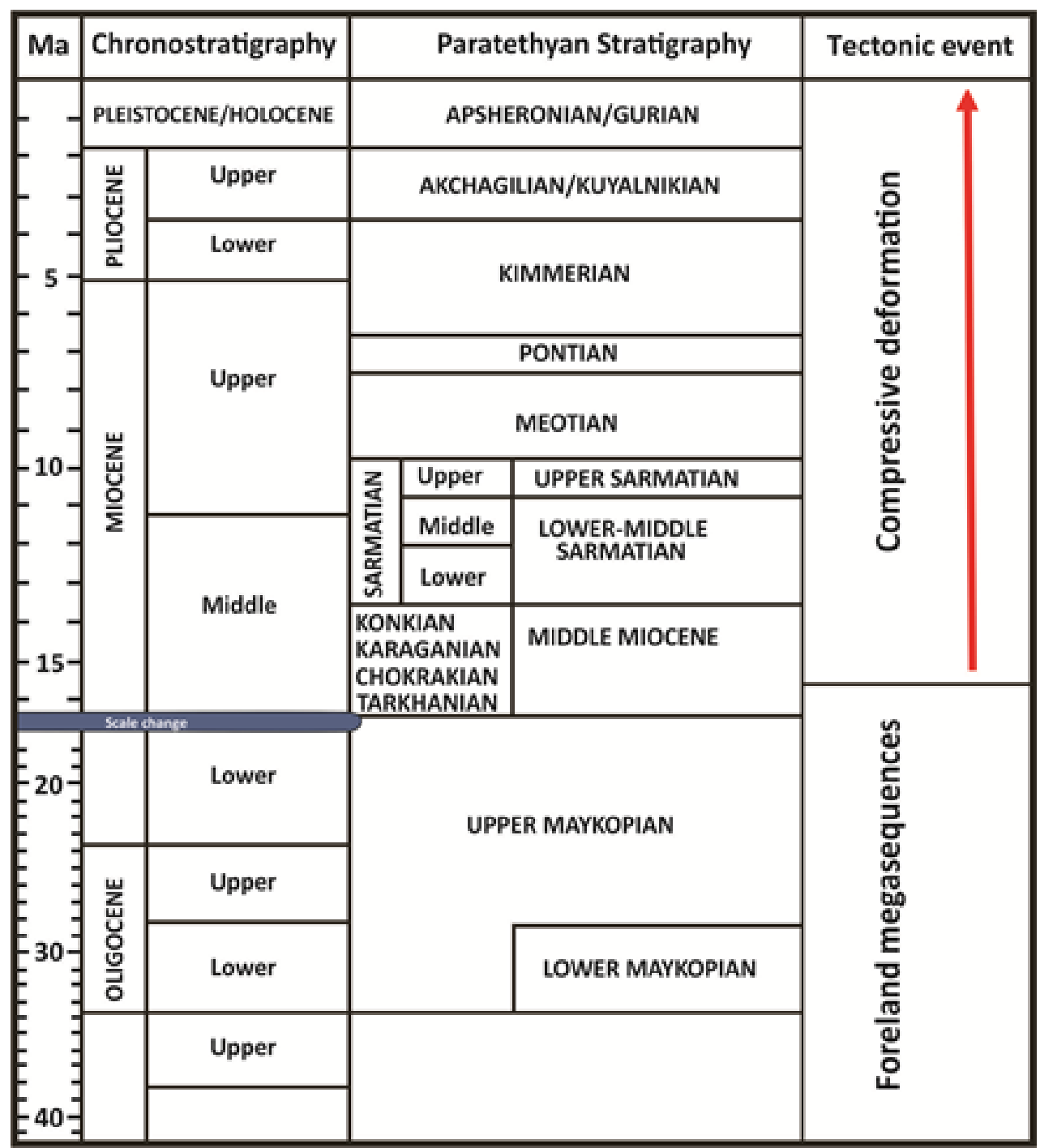

Figure 3. Stratigraphic column of the study area (Modified after [5]) 


\section{Structural Interpretation of the Seismic Profile}

Fault-related folding theories [18, 19] were used for structural interpretation of the $\mathrm{S}-\mathrm{N}$ trending $23.7 \mathrm{~km}$. long seismic reflection (time-migration) profile $\mathrm{A}-\mathrm{B}$ in the Georgian part of KFFTB (Figure 2). The surface geological information, shallow and deep oil-well data (Nazarlebi-1, 2, 4, 5 \& Shiraki-73, 81, 82) have been applied as well. Seismic reflection data reveal the presence of south-vergent thrusts $\left(F_{1}, F_{2}, F_{3}, F_{4}\right)$, north-vergent backthrusts $\left(\mathrm{Bt}_{1}, \mathrm{Bt}_{2}, \mathrm{Bt}_{3}\right)$, and duplex (Figure 4).

The northern part of profile (Alazani basin area) is covered by Quaternary sediments and the north-vergent faults $\left(\mathrm{Bt}_{1}\right)$ do not clearly appear at surface. Nevertheless, the seismic profiles clearly show the three major faults and associated subsurface structures (Figure 4). These faults are also steeply dipping at the surface whereas they dip gently at depth. The faults have formed as thrust imbricates. Other structures at the KFFTB can be interpreted in this seismic profile. In the frontal area of the Mirzaani-Nazarlebi area there is a triangle zone (Figure 4). The deformations in the KFFTB structures were controlled by the multi-level detachments. Imbricate structures are represented by south and north vergent fault-related folds and duplex.

The shallow-level detachment in the upper Miocene develops fault-related folds (south-and north-vergent fault-propagation folds). The medium-level and deep-level detachments in the middle Miocene and Maikopian suite
(Oligocene-Lower Miocene) develops south-vergent thrusts and duplex. Both the shallow and the deep detachments transfer its slip to the south and made another deformation inner the Kura foreland basin (Figure 4).

\section{Discussion}

\subsection{The Structural Model for the Georgian Part of Kura Foreland Fold-and-Thrust Belt}

The seismic profiles show that the structure and style of deformation of the Kura foreland fundamentally differs from a 'simple' thrust model [e.g. 9, 10, 11]. Building of structures of the Kura foreland basin was formed by Greater Caucasus basement wedge propagation along detachment horizons within the cover-generating thin-skinned structures represented by Neogene shallow marine and thick continental sediments. Based on the structural style of deformation, two seismic-structural complexes were identified in seismic profiles: an upper and a lower complex. South-verging wedge structures are represented by an allochthon duplex confined by faults from the top and bottom. The geometry of the south-vergent duplex present in the lower structural complex is clearly visible on the migrated time seismic profile for A-B (Figure 4). South-vergent backthrust and north-vergent forethrust units are represented by fault-related folds and are interpreted as an asymmetric break through fault-propagation folding.
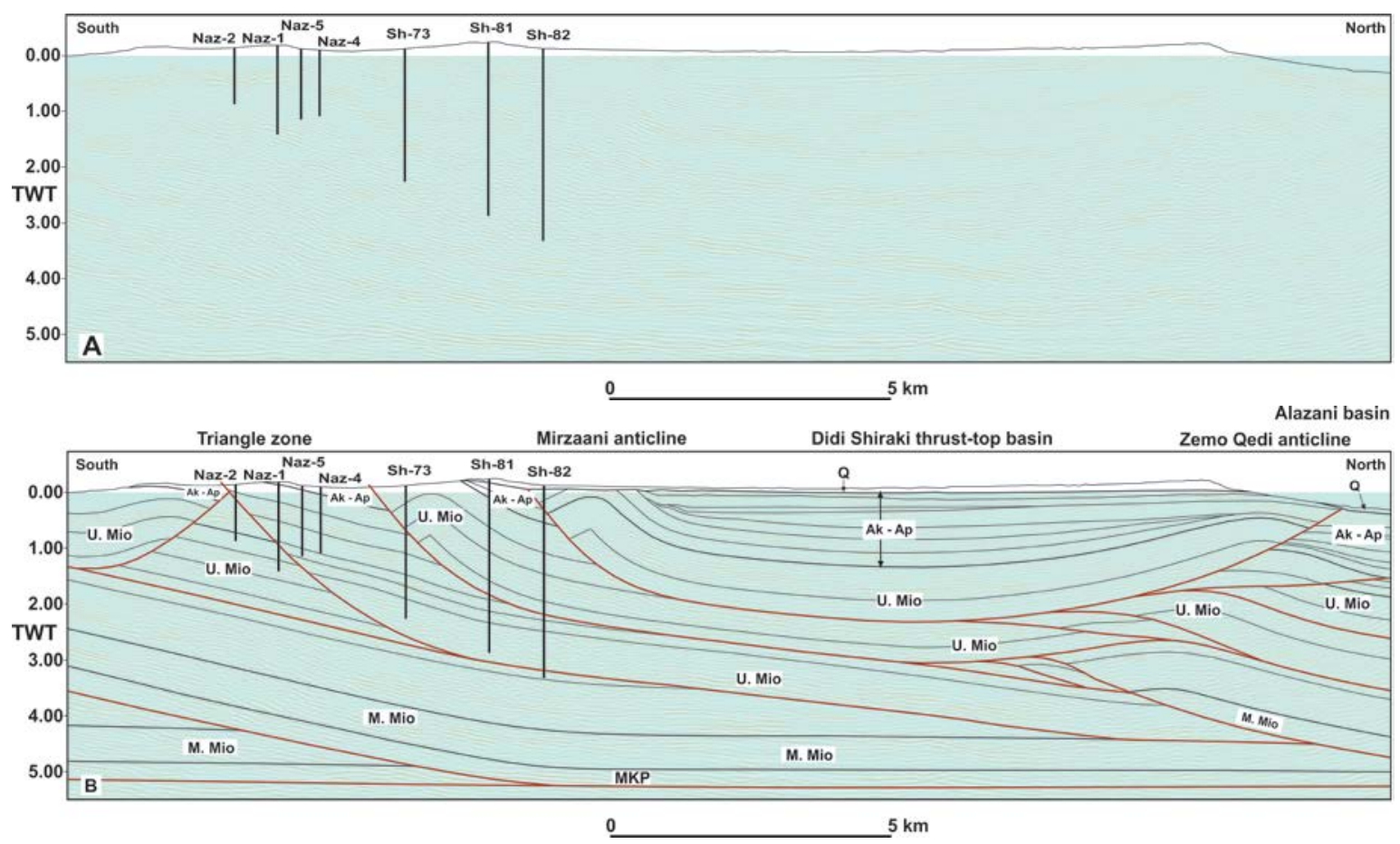

Figure 4. (A) Uninterpreted and (B) interpreted seismic reflection profiles A-B. Location is shown in Figure 2. Abbreviatures: MKP - Maikopian (Oligocene-Lower Miocene), M. Mio - Middle Miocene, U. Mio - Upper Miocene, Ak-Ap - Akchagilian-Apsheronian (Pliocene-Pleistocene), Q Quaternary 


\subsection{Didi Shiraki Thrust-top Basin}

Interpreted seismic profiles (A-B) have clearly revealed that the Didi Shiraki syncline due to geometrical features of Pliocene-Pleistocene growth strata is a thrust-top basin (Figs. 4 and 5). The geometry of growth (or syn-kinematic) strata as well as northward and southward migration of the basin depocenter is well-observed on the seismic profile. Related to the Didi Shiraki thrust double migration of the basin depocenter was linked to the formation of Zemo Kedi and Mirzaani fault-related folds (Figure 5). Specific deformed shapes are developed in Pliocene (Akhchagilian) sediments of the Didi Shiraki syncline. They form single sequences disposed with unconformity on the backlimbs of Mirzaani (to the South) and Zemo Kedi (to the North) anticlines. Overlying the Pliocene sediments Pleistocene (Apsheronian) strata in the seismic profile could represent the later deformation stage. Deformed growth strata folds are characterized by inclined toward the synclinal axis scarps. During each subsequent stage of compression termination of growth strata underwent deformation towards the limbs of anticlines. Developed in the growth strata surfaces of angular unconformities are clearly observed on the seismic profile (A-B) (Figure 5). Developed on the backlimb of the Mirzaani and Zemo Kedi anticlines growth strata sequences are characterized by variation of dip angles. Similar types of growth strata (Figure 6) are related to the model of folding constrained by king-band migration [e.g. 20]. The unconformity in the growth folds is mainly caused by the fold kinematics namely, by active anticlinal and synclinal axis kink-band migration and progressive limb rotation [20] (Figure 6) and are identified in the interpreted seismic reflection profile (Figs. 4 and 5). Formation of Zemo Kedi fault-related fold is related to the kinematics of the north vergent duplexes below it. Consequently, the development of the related to Didi Shiraki thrust basin took place above the bivergent structure. Due to its geometry and kinematic features the basin related to the Didi Shiraki thrusts has much in common with the Alto beni basin [e.g. 21].

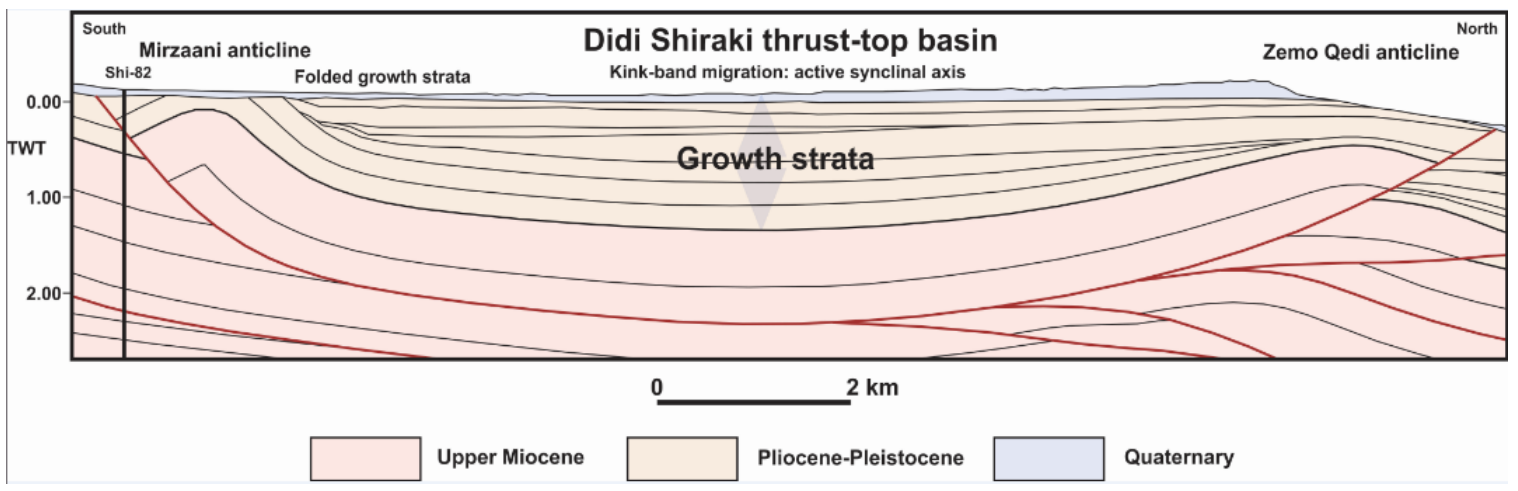

Figure 5. interpreted line drawing seismic section A-B (fragment)
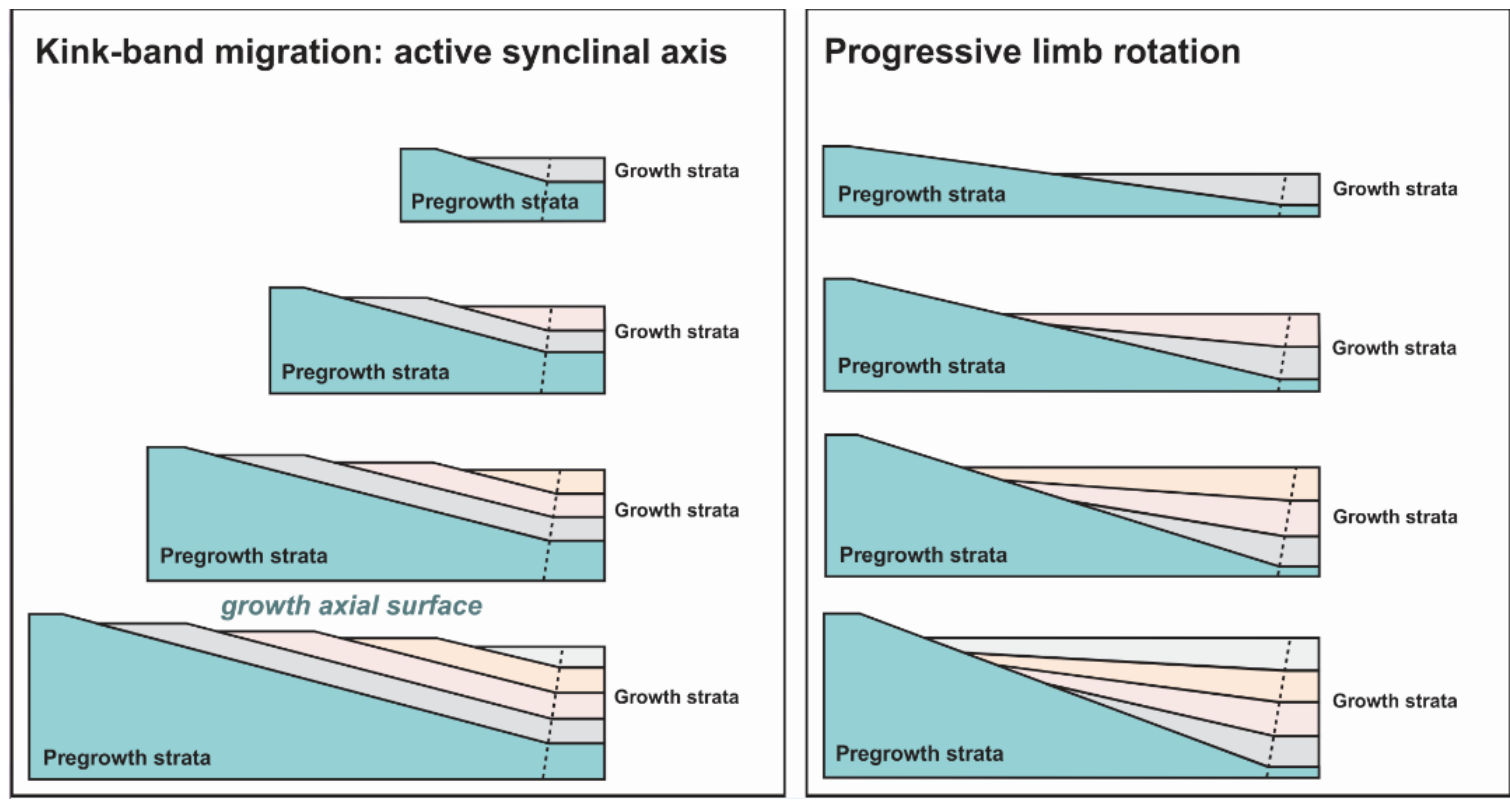

Figure 6. Kinematic models illustrating the onlap patterns in growth folds that develop by kink-band migration and limb rotation [20] 


\section{Conclusions}

(1) According to the introduced here interpreted seismic reflection profile, the Kura foreland is an active thin-skinned FTB.

(2) The deformations in the KFFTB structures were controlled by the multi-level detachments. Imbricate structures are represented by south and north vergent fault-related folds and duplex. The shallow-level detachment in the upper Miocene develops fault-related folds (south-and north-vergent fault-propagation folds). The medium-level and deep-level detachments in the middle Miocene and Maikopian suite (Oligocene-Lower Miocene) develops south-vergent thrusts and duplex. Both the shallow and the deep detachments transfer its slip to the south and made another deformation inner the Kura foreland basin.

(3) The Didi Shiraki thrust-top basin has a bivergent geometry and is filled by Pliocene and Pleistocene syn-kinematic sediments.

\section{Acknowledgements}

We thank to Midland Valley for providing the Move program through their Academic Support Initiative Programme. Seismic sections were kindly made available by the Oil Company Frontera Eastern Georgia Ltd. We sincerely thank two anonymous reviewers whose careful and thorough comments significantly improved this paper.

\section{REFERENCES}

[1] V. Alania, A. Chabukiani, R. Chagelishvili, O. Enukidze, K. Gogrichiani, A. Razmadze, N. Tsereteli. Growth structures, piggy-back basins and growth strata of Georgian part of Kura foreland fold and thrust belt: implication for Late Alpine kinematic evolution, Geological Society, London, Special Publications, Vol.428, 171-185, 2017.

[2] Mosar, J., et al. 2010. Cenozoic-Recent tectonics and uplift in the Greater Caucasus: a perspective from Azerbaijan, Geological Society of London, Special Publication, Vol.340, 261-79, 2010.

[3] M. Sosson et al. Subductions, obduction and collision in the Lesser Caucasus (Armenia Azerbaijan, Georgia), new insights, Geological Society of London, Special Publication, Vol.340, 329-52, 2010.

[4] Sh. Adamia, V. Alania, G. Ananiashvili, E. Bombolakis, G. Chichua, D. Girshiashvili, R. Martin, and L. Tatarashvili. Late Mesozoic-Cenozoic geodynamic evolution of the eastern Georgian oil-gas bearing basins, Geologica Carpathica, Vol.53, 155-159, 2002.

[5] Sh. Adamia, V. Alania, A. Chabukiani, G. Chichua, O. Enukidze, N. Sadradze. Evolution of the Late Cenozoic basins of Georgia (SW Caucasus): a review, Geological Society, London, Special Publication, Vol.340, 239-259, 2010.

[6] V. Alania, O. Enukidze, K. Koiava, A. Razmadze, A. Sanishvili. Thrust systems and time of deformation of the Gare Kakheti foothills, eastern Georgia (Georgia), An International Journal of Earth Science - Bollettino di Geofisica, teorica ed applicata, Vol.49 (SUPPLEMENT), 207-208, 2008.

[7] Forte, E. Cowgill, T. Bernardin, O. Kreylos, B. Hamann. Late Cenozoic deformation of Kura fold-thrust belt, southern Greater Caucasus, Geological Society of America Bulletin, Vol.122, 465-486, 2010.

[8] M. Nemcok, et al. Development history of the foreland plate trapped between two converging orogens; Kura Valley, Georgia, case study, Geological Society, London, Special Publications, Vol.377, 159-188, 2013.

[9] L. Basheleishvili, M. Kumelashvili. Geometry and genesis of thrust structures of the molasse depression of the Eastern Georgia, Georgian Oil and Gaz, Vol.14, 39-46, 2005 [in Russian].

[10] V. Khain. Structure and main stages in the tectonomagmatic development of the Caucasus: An attempt at geodynamic interpretation, American Journal of Science, Vol.275, 131156, 1975.

[11] H. Philip, A. Cisternas, A. Gvishiani, A. Gorshkov. The Caucasus: an actual example of the initial stages of continental collision, Tectonophysics, Vol.161, 1-21, 1989.

[12] G. G. Ori, P. G. Friend. Sedimentary basins, formed and carried piggyback on active thrust sheets, Geology, Vol.12, 475-478, 1984.

[13] G. DeCelles, K. Giles. Foreland basin systems, Basin Research, Vol.8, 105-123, 1996.

[14] M. Bonini, G. Moratti, F. Sani. Evolution and depocentre migration in thrust-top basins: inferences from the Messinian Velona Basin (Northern Apennines, Italy), Tectonophysics, Vol.304, 95-108, 1999.

[15] R. E. Reilinger, et al. GPS constraints on cintinental deformation in the Africa-Arabia-Eurasia continental collision zone and implications for the dynamics of plate interactions, Journal of Geophysical Research, Vol.111(B5), 1-26, 2006.

[16] M. Ioseliani. Structure of the Lithosphere of the Georgia by Seismic Data. Metsniereba, Tbilisi, 1989 [in Russian].

[17] V. Chkhikvadze, et al. Review of the localities of Tertiary Vertebrates of Georgia, Proceedings of Geological Institute of Academy of Sciences of Georgia, Vol.115, 153-163, 1999 (in Russian).

[18] J. Suppe. Geometry and kinematics of fault-bend folding, American journal of Science, Vol.283. 684 - 721, 1983.

[19] J. Shaw, C. Connors, J. Suppe. Part 1: Structural Interpretation Methods, In: Seismic Interpretation of Contractional Fault-Related Folds, An AAPG Seismic Atlas, American Association of Petroleum Geologists Special Publication, 1-58, 2004.

[20] S. Hardy, J. Poblet. Geometric and numerical model of 
progressive limb rotation in detachment folds, Geology Vol.22, 371-374, 1994.

[21] Patrice, B. Colletta, D. Zubieta. Geometric and experimental study of a piggyback basin: example of the Alto Beni synclinorium, central Andes, Bulletin de la Societe Geologique de France, Vol.166, 797-811, 1995. 